\title{
Assessment of heavy metals and its impact on DNA fragmentation in different fish species
}

\author{
S. Sultana ${ }^{a}$ (D), F. Jabeen ${ }^{a}$ (D), T. Sultana ${ }^{a}$ (D), K. A. AL-Ghanim ${ }^{b}$ (D), F. Al-Misned ${ }^{b}$ (D) and \\ S. Mahboob ${ }^{a, b *}$

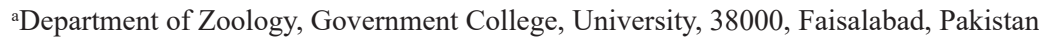 \\ ${ }^{b}$ Department of Zoology, College of Science, King Saud University, Kingdom of Saudi Arabia \\ *e-mail: shahidmahboob60@hotmail.com
}

Received: March 27, 2019 - Accepted: July 31, 2019 - Distributed: November 30, 2020

\begin{abstract}
This study was conducted to assess water pollution by examining DNA fragmentation in selected fish organs (kidney, liver, gills, and muscle tissue) from Wallago attu, Sperata sarwari, Vulgaris vulgaris, and Labeo rohita collected from a known polluted section of the Chenab River, Pakistan, and from a control site. The fish were caught using a gill net and were assigned to three different weight groups (W1, W2, and W3) to study the degree of variation in DNA fragmentation in relation to body weight. In fish from the polluted site, DNA fragmentation was higher in kidney, liver, gills, and muscles, compared to the control. No significant DNA fragmentation was observed in fish collected from the control site. Highly significant $(\mathrm{P}<0.01)$ relationship between body weight and DNA fragmentation was found in the organs of fish procured at the contaminated site. DNA fragmentation in body organs was found to be affected by the concentrations of lead, copper, nickel, and cadmium in W. attu, S. sarwari, L. rohita, and V. vulgarus harvested from Chenab River. DNA fragmentation in different freshwater fish species is therefore a reliable biomarker of water pollution.
\end{abstract}

Keywords: heavy metals, fish, body weight, organs, DNA fragmentation.

\section{Avaliação de metais pesados e seu impacto na fragmentação de DNA em diferentes espécies de peixe}

\section{Resumo}

Este estudo foi conduzido para avaliar a poluição da água examinando a fragmentação do DNA em órgãos de peixes selecionados (rim, fígado, brânquias e tecido muscular) de Wallago attu, Sperata sarwari, Vulgaris vulgaris e Labeo rohita coletados de uma conhecida área poluída do rio Chenab, Paquistão e de um local de controle. Os peixes foram capturados usando uma rede branquial e foram divididos em três grupos de pesos diferentes (W1, W2 e W3) para estudar o grau de variação na fragmentação do DNA em relação ao peso corporal. Nos peixes do local poluído, a fragmentação do DNA foi maior nos rins, fígado, brânquias e músculos, em comparação ao controle. Não foi observada fragmentação significativa do DNA em peixes coletados no local de controle. Relação altamente significativa $(\mathrm{P}<0,01)$ entre o peso corporal e a fragmentação do DNA foi encontrada nos órgãos dos peixes adquiridos no local contaminado. Verificou-se que a fragmentação do DNA nos órgãos do corpo é afetada pelas concentrações de chumbo, cobre, níquel e cádmio em W. attu, S. sarwari, L. rohita e V. vulgarus colhidos no rio Chenab. A fragmentação do DNA em diferentes espécies de peixes de água doce é, portanto, um biomarcador confiável da poluição da água.

Palavras-chave: metais pesados, peixe, peso corporal, órgãos, fragmentação do DNA.

\section{Introduction}

Successful aquaculture depends on a continuous supply with pollution free water because fish is more sensitive to water pollutants. Water can potentially be polluted with suspended solids, nutrients, heavy metals, organic matter, pesticides, and industrial chemicals (Boyd and Tucker, 1998). Rivers, streams, and other water bodies are often vulnerable to contaminants to organic and inorganic chemical toxicants, which has shown to produce detrimental effects on fauna and flora in aquatic

ecosystem (Wood, 2001). The rapid industrialization and urbanization is one of the most factors for increase in water pollution and becoming a serious challenge for the environmentalists (Mayon et al., 2006). There is a dire need, to evaluate the effect of pollution on biomarkers such as DNA fragmentation (Hussain et al., 2016). The aquatic fauna and flora is exposed to the pesticides and heavy metals, which is main the main of genotoxicity in fish (Souza and Fontanetti, 2006; Santos et al., 2014; Saeedi 
Table 1. Categorization of experimental (Exp.) and control (Cont.) fish (mean weight in g) in three different weight categories.

\begin{tabular}{cccrrrrrr}
\hline $\begin{array}{c}\text { Weight } \\
\text { category }\end{array}$ & \multicolumn{2}{c}{$\begin{array}{l}\text { Wallago attu } \\
\text { Pollu. Cont. }\end{array}$} & \multicolumn{2}{c}{$\begin{array}{c}\text { Sperata sarwari Pollu. } \\
\text { Cont. }\end{array}$} & \multicolumn{2}{c}{$\begin{array}{c}\text { Labeo rohita } \\
\text { Pollu. Cont. }\end{array}$} & \multicolumn{2}{c}{$\begin{array}{c}\text { Vulgaris vulgaris } \\
\text { Pollu. Cont. }\end{array}$} \\
\hline W1 & 862.24 & 831.46 & 596.88 & 597.83 & 194.44 & 184.45 & 232.43 & 230.81 \\
W2 & 1158.84 & 1140.59 & 1133.95 & 1143.25 & 562.91 & 539.16 & 265.25 & 258.74 \\
W3 & 1460.72 & 1440.3 & 1320.39 & 1312.95 & 826.31 & 793.96 & 292.28 & 284.30 \\
\hline
\end{tabular}

Pollu. $=$ Polluted; Cont.$=$ Control.

Saravi and Shokrzadeh, 2013). The increasing loads of these toxicants pollute the freshwater ecosystem and pose serious human health risks (Zhao et al., 2014).

Fish are physiologically affected by pollutants in their environment, and fish abundance is typically a function of water quality (Aleya et al., 2007; Hued and Bistoni, 2005). Furthermore, fish, play key and important role in community structure in the food web. Previous results mentioned that trace metals may adversely affect

[...] cellular organelles and components such as nucleic and mitochondrial DNA; moreover, heavy metals may inhibit several enzymes involved in DNA damage repair which causes DNA damage and conformational changes that may lead to cell cycle modulation and apoptosis (Wang and Shi, 2001).

DNA fragmentation changes have been associated with pollutant exposure in C. carpio, however, the patterns of DNA fragmentation seem to depend on tissue type. DNA extracted from fins showed a higher proportion of fragmentation than that of tissues (Salman et al., 2012). Liyan et al. (2005) suggested DNA fragmentation status is a reliable indicator of genotoxicity in aquatic organisms in polluted environments. The objective of this research work was (i) to investigate the effects of heavy metal exposure on DNA fragmentation; (ii) and to assess a potential correlation of fish weight; and (iii) DNA fragmentation in Wallago attu, Sperata sarwari, Valgarius valgarius, and Labeo rohita harvested from Chenab River.

\section{Material and Methods}

\subsection{Study area and selection criteria}

Fish procured from the Chenab River near Chiniot, Pakistan, were used in this study. The city of Chiniot is located on the left bank of the Chenab River at a latitude of $31.7200^{\circ}$ and a longitude of $72.9789^{\circ}$. Fish caught from Chenab River are a regionally popular source of food. Effluents from adjacent industries and domestic sources discharge into the Chakbandi drain and it adds into Chenab River.

\subsection{Sample collection}

Forty-eight $(\mathrm{N}=12)$ for each species samples of Wallago attu, Sperata sarwari, Vulgaris vulgaris, and Labeo rohita were procured from a polluted site of the Chenab River, and control fish were obtained from a commercial fish farm. The sampled live fish were transported to the laboratory and morphometric characteristics (body weight and length) were recorded. The weight and standard length of the fish species of the polluted and control site, respectively, were as follows: $W$. attu $750-1550 \mathrm{~g}$ and $18.5-22.7 \mathrm{~cm}, S$. sarwari $500-1360 \mathrm{~g}$ and $14.2-45.1 \mathrm{~cm}$, V. vulgaris $225-350 \mathrm{~g}$ and 9.6-12.6 cm, and L. rohita $150-950 \mathrm{~g}$ and $18.5-22.7 \mathrm{~cm}$. Each fish species was categorized into three weight groups (W1, W2 and W3) as mentioned in Table 1.

\subsection{Fish dissection and preservation}

Each fish was dissected, and $10 \mathrm{~g}$ samples of kidney, liver, gills, and muscle were collected. Each sample was removed individually and placed in marked sterilized polyethylene bags for storage at $-20{ }^{\circ} \mathrm{C}$ until DNA fragmentation analyses.

\subsection{DNA fragmentation}

DNA fragmentation was studied in the kidney, liver, gills, and muscle using a Bichrome Libra S12 UV/Vis spectrophotometer and following the method of Perandones et al. (1993).

\subsection{Assessment of heavy metals}

The aim of this study was also to evaluate heavy metals in the different fish organs, as this may be an early indicator of freshwater pollution in order to safeguard the quality of aquatic life to promote fish production. Heavy metals were analyzed using an Atomic Absorption Spectrophotometer (Hitachi Polarized Zeeman AAS, Z-8200, Japan) following the methods described in AOAC (1995). The concentrations of cadmium $(\mathrm{Cd})$, copper $(\mathrm{Cu})$, lead $(\mathrm{Pb})$, and nickel $(\mathrm{Ni})$ were measured.

\subsection{Statistical analysis}

Data are presented as means \pm S.E. Statistical analyses were performed using a two-way analysis of variance followed by a Tukey's test. The correlation of weight and different organs regarding DNA fragmentation (in percent) and heavy metals was worked out.

\section{Results}

\subsection{Heavy metals in fish organs}

In weight group $\mathrm{W} 1$, a maximum $\mathrm{Pb}$ level of $5.5 \mathrm{mg} / \mathrm{kg}$ was found in the liver of $S$. sarwari, whereas no $\mathrm{Pb}$ was found in liver, gills, and muscle of $W$. attu, and in muscle tissue of $S$. sarwari. In weight group W2, a maximum $\mathrm{Pb}$ level of $7.5 \mathrm{mg} / \mathrm{kg}$ was detected in the liver of $S$. sarwari, and no $\mathrm{Pb}$ was found in kidney and gills of $W$. attu, and in muscle tissue of $S$. sarwari. In category W3, a maximum $\mathrm{Pb}$ concentration of $8.5 \mathrm{mg} / \mathrm{kg}$ was detected in the liver 
of $S$. sarwari, and no $\mathrm{Pb}$ was found in muscle tissue of $S$. sarwari (Table 2). The maximum concentrations of $\mathrm{Cu}$ were $9.0,8.5$, and $6.5 \mathrm{mg} / \mathrm{kg}$ in the liver of $S$. sarwari, W. attu and $V$. vulgaris of weight group W3, W2, and W1, respectively. No $\mathrm{Cu}$ was detected in the muscle of $S$. sarwari and W. attu of weight groups W1, W2, and W3 (Table 2).

In weight group W1, the highest Ni concentration of $4 \mathrm{mg} / \mathrm{kg}$ was found in the liver and kidney of $L$. rohita and no Ni was found in "liver and muscle tissue" of $W$. attu and L. rohita, and in gills of S. sarwari; the maximum $\mathrm{Ni}$ concentration of $5.5 \mathrm{mg} / \mathrm{kg}$ was detected in the liver of W. attu. In weight group W2, no Ni was detected in muscle tissue and gills of W. attu and $S$. sarwari. In weight group $\mathrm{W} 3$, the maximum Ni concentration of $8 \mathrm{mg} / \mathrm{kg}$ was found in the kidney of L. rohita, whereas no Ni detected in the liver of $W$. attu (Table 2). The maximum Cd concentration in weight group W1 was $3.5 \mathrm{mg} / \mathrm{kg}$ and was found in the kidney of $L$. rohita. No Cd was detected in gills of $W$. attu, $S$. sarwari, and $V$. vulgaris and in muscle tissue of L. rohita and $V$. valgarius. In categories $\mathrm{W} 2$ and $\mathrm{W} 3$ the maximum Cd concentrations of 3.5 and $4.5 \mathrm{mg} / \mathrm{kg}$, respectively, were found in the kidney of $V$. vulgaris. No Cd was detected in gills and muscle tissue of $W$. attu and in the gills of S. sarwari of weight group W3 (Table 2).

\subsection{DNA fragmentation in fish organs}

The percentages of DNA fragmentation (minimum - maximum) in "kidney, liver, gills, and muscle tissue" of $W$. attu and S. sarwari collected from the polluted site were $62.75-75.12 \%, 57.17-63.57 \%, 56.83-61.91 \%$, and $44.21-52.37 \%$, and $58.13-70.16 \%, 55.12-62.23 \%$, $54.12-60.41 \%$, and $34.52-52.02 \%$, respectively. DNA fragmentation percentages in kidney, liver, gills, and muscle tissue of $W$. attu and $S$. sarwari from the control site were $47.29-45.12 \%, 35.12-38.61 \%, 31.21-36.75 \%$, and $27.21-35.12 \%, 45.12-47.29 \%, 35.12-38.61 \%$, $31.21-36.75 \%$, and $27.21-35.12 \%$, respectively. DNA fragmentation in kidney, liver, gills, and muscle tissue was positive and significantly $(\mathrm{P}<0.01)$ correlated with fish weight (Table 3). No DNA fragmentation was observed in organs of $W$. attu and $S$. sarwari harvested from the control site. In S. sarwari, DNA fragmentation

Table 2. Level of $\mathrm{Pb}, \mathrm{Cu}, \mathrm{Ni}$, and $\mathrm{Cd}(\mathrm{mg} / \mathrm{kg})$ in kidney, liver, gills, and muscle tissue in different weight categories of the three fish species.

\begin{tabular}{|c|c|c|c|c|c|c|c|c|c|c|c|c|c|c|c|c|}
\hline \multirow[b]{2}{*}{$\begin{array}{c}\text { Wt. } \\
\text { group }\end{array}$} & \multicolumn{4}{|c|}{ Wallago attu } & \multicolumn{4}{|c|}{ Sperata sarwari } & \multicolumn{4}{|c|}{ Labeo rohita } & \multicolumn{4}{|c|}{ Vulgaris vulgaris } \\
\hline & 莺 & : & 昜 & $\begin{array}{l}\frac{0}{e} \\
\stackrel{\mathscr{E}}{\Xi}\end{array}$ & 尝 & $\stackrel{\bar{d}}{\grave{3}}$ & 葛 & $\begin{array}{l}\frac{0}{0} \\
\text { 总 } \\
\sum\end{array}$ & $\frac{\vec{\partial}}{\stackrel{3}{3}}$ & 方 & 竞 & 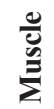 & 冚 & $\sum_{3}^{\frac{3}{3}}$ & 竞 & $\begin{array}{l}\frac{0}{e} \\
\stackrel{E}{\Xi}\end{array}$ \\
\hline & \multicolumn{16}{|c|}{$\mathbf{P b}$} \\
\hline 1 & 1 & 0 & 0 & 0 & 2.5 & 5.5 & 3 & 0 & 3.5 & 3 & 2 & 1.5 & 2.5 & 2 & 1 & 1 \\
\hline 2 & 0 & 4.5 & 0 & 1 & 3.5 & 7.5 & 4 & 0 & 4.5 & 3 & 3.5 & 2 & 3.5 & 2 & 1 & 1 \\
\hline \multirow[t]{2}{*}{3} & 2 & 4.5 & 7 & 2 & 5 & 8.5 & 5 & 0 & 5 & 4.5 & 4.5 & 3 & 4 & 3 & 1.5 & 2 \\
\hline & \multicolumn{16}{|c|}{$\mathrm{Cu}$} \\
\hline 1 & 3.5 & 6.5 & 6 & 2 & 2 & 4.5 & 3 & 0 & 4 & 4 & 2.5 & 0.5 & 2.5 & 2 & 1.5 & 1.5 \\
\hline 2 & 5 & 4.7 & 3 & 0 & 3 & 8.5 & 3.5 & 0 & 5 & 4.5 & 3 & 2 & 3 & 2.5 & 2 & 1.5 \\
\hline \multirow[t]{2}{*}{3} & 3 & 4 & 3 & 1 & 6 & 9 & 3.5 & 0 & 7 & 5 & 6 & 4 & 3 & 3 & 2.5 & 2 \\
\hline & \multicolumn{16}{|c|}{$\mathrm{Ni}$} \\
\hline 1 & 2.5 & 0 & 2.5 & 0 & 1.5 & 3 & 0 & 0.5 & 4 & 4 & 1.5 & 0 & 1 & 2 & 1.5 & 1 \\
\hline 2 & 1 & 5.5 & 2.5 & 0 & 3.5 & 4 & 0 & 0.5 & 5 & 5 & 2.5 & 2 & 1.5 & 3 & 2 & 1 \\
\hline \multirow[t]{2}{*}{3} & 3 & 0 & 1 & 1 & 5.5 & 5 & 5 & 1 & 8 & 7 & 3 & 4 & 2 & 3.5 & 2 & 2.5 \\
\hline & \multicolumn{16}{|c|}{ Cd } \\
\hline 1 & 0.5 & 0.5 & 0 & 0.5 & 0.5 & 0.5 & 0 & 0.5 & 3.5 & 2 & 1.5 & 0 & 2.5 & 2 & 0 & 0 \\
\hline 2 & 1.5 & 1.5 & 0.5 & 1 & 0 & 0.5 & 0 & 1 & 3 & 2 & 2.5 & 1.5 & 3.5 & 2.5 & 2.5 & 1.5 \\
\hline 3 & 1.5 & 0.5 & 0 & 0 & 1.5 & 1.2 & 0 & 2 & 4 & 3 & 3 & 3 & 4.5 & 3 & 3 & 2 \\
\hline
\end{tabular}

Table 3. Correlation matrix of weight and DNA fragmentation in different organs in Wallago attu.

\begin{tabular}{|c|c|c|c|c|c|}
\hline & Weight & Kidney & Liver & Gills & Muscle \\
\hline Weight & 1.000 & & & & \\
\hline \multirow[t]{2}{*}{ Kidney } & $0.990 * *$ & 1.000 & & & \\
\hline & 0.000 & & & & \\
\hline \multirow[t]{2}{*}{ Liver } & $0.989 * *$ & $0.977 * *$ & 1.000 & & \\
\hline & 0.000 & 0.000 & & & \\
\hline \multirow[t]{2}{*}{ Gills } & $0.973 * *$ & $0.960 * *$ & $0.960 * *$ & 1.000 & \\
\hline & 0.000 & 0.000 & 0.000 & & \\
\hline \multirow[t]{2}{*}{ Muscle } & $0.948 * *$ & $0.934 * *$ & $0.959 * *$ & $0.966 * *$ & 1.000 \\
\hline & 0.000 & 0.000 & 0.000 & 0.000 & \\
\hline
\end{tabular}

Values in the top line of each tissue indicate Pearson's correlation coefficient; values in the respective bottom line indicate level of significance at $5 \%$ probability. **highly significant $(\mathrm{P}<0.01)$. 
in "kidney, liver, gills and muscle tissue" was positively and significantly $(\mathrm{P}<0.01)$ correlated with weight (Table 4). DNA fragmentation in kidney, liver, gills, and muscle tissue of $L$. rohita collected from the polluted site were 28.17-64.25\%, 26.13-59.64\%, 24.17-58.40\%, 22.12-50.19\%. DNA fragmentation in kidney, liver, gills, and muscle tissue of $L$. rohita collected from the control site were $20.94-40.82 \%, 20.21-35.99 \%, 19.96-35.62 \%$ and $18.82-34.62 \%$, respectively. The correlation of fish weight and DNA fragmentation in kidney, liver, gills, and muscle tissue was positive and highly significant $(\mathrm{P}<0.01$; Table 5). In . valgaris from the polluted site,
DNA fragmentation in kidney, liver, gills, and muscle tissue was 32.51-41.11\%, 30.17-37.98\%, 28.72-36.01\%, and $20.12-28.13 \%$. DNA fragmentation in $V$. valgaris from the control site in kidney, liver, gills, and muscle tissue was $25.12-25.22 \%, 22.27-23.29 \%, 21.12-21.91 \%$, and 19.21-21.45\%, respectively, at the control site. DNA fragmentation in kidney, liver, gills, and muscle tissue and fish weight were positively and significantly correlated $(\mathrm{P}<0.01$; Table 6). Muscle tissue exhibited the smallest percentage of DNA fragmentation, whereas kidney, liver, and gills were significantly affected, in descending order.

Table 4. Correlation matrix of weight and DNA fragmentation in different organs in Sperata sarwari.

\begin{tabular}{|c|c|c|c|c|c|}
\hline & Weight & Kidney & Liver & Gills & Muscle \\
\hline Weight & 1.000 & & & & \\
\hline \multirow[t]{2}{*}{ Kidney } & $0.997 * *$ & 1.000 & & & \\
\hline & 0.000 & & & & \\
\hline \multirow[t]{2}{*}{ Liver } & $0.985 * *$ & $0.983 * *$ & 1.000 & & \\
\hline & 0.000 & 0.000 & & & \\
\hline \multirow[t]{2}{*}{ Gills } & $0.971 * *$ & $0.978 * *$ & $0.983 * *$ & 1.000 & \\
\hline & 0.000 & 0.000 & 0.000 & & \\
\hline \multirow[t]{2}{*}{ Muscle } & $0.937 * *$ & $0.953 * *$ & $0.964 * *$ & $0.972 * *$ & 1.000 \\
\hline & 0.000 & 0.000 & 0.000 & 0.000 & \\
\hline
\end{tabular}

Values in the top line of each tissue indicate Pearson's correlation coefficient; values in the respective bottom line indicate level of significance at $5 \%$ probability. $* *$ highly significant $(\mathrm{P}<0.01)$.

Table 5. Correlation matrix for weight and DNA fragmentation in different organs in Labeo rohita.

\begin{tabular}{|c|c|c|c|c|c|}
\hline & Weight & Kidney & Liver & Gills & Muscle \\
\hline Weight & 1.000 & & & & \\
\hline \multirow[t]{2}{*}{ Kidney } & $0.973 * *$ & 1.000 & & & \\
\hline & 0.000 & & & & \\
\hline \multirow[t]{2}{*}{ Liver } & $0.969 * *$ & $0.999 * *$ & 1.000 & & \\
\hline & 0.000 & 0.000 & & & \\
\hline \multirow[t]{2}{*}{ Gills } & $0.964 * *$ & $0.994 * *$ & $0.996 * *$ & 1.000 & \\
\hline & 0.000 & 0.000 & 0.000 & & \\
\hline \multirow[t]{2}{*}{ Muscle } & $0.993 * *$ & $0.981 * *$ & $0.979 * *$ & $0.981 * *$ & 1.000 \\
\hline & 0.000 & 0.000 & 0.000 & 0.000 & \\
\hline
\end{tabular}

Values in the top line of each tissue indicate Pearson's correlation coefficient; values in the respective bottom line indicate level of significance at $5 \%$ probability. $* *$ highly significant $(\mathrm{P}<0.01)$.

Table 6. Correlation matrix for weight and DNA fragmentation in different organs in Vulgaris vulgaris.

\begin{tabular}{|c|c|c|c|c|c|}
\hline & Weight & Kidney & Liver & Gills & Muscle \\
\hline Weight & 1.000 & & & & \\
\hline \multirow[t]{2}{*}{ Kidney } & $0.973 * *$ & 1.000 & & & \\
\hline & 0.000 & & & & \\
\hline \multirow[t]{2}{*}{ Liver } & $0.969 * *$ & $0.999 * *$ & 1.000 & & \\
\hline & 0.000 & 0.000 & & & \\
\hline \multirow[t]{2}{*}{ Gills } & $0.964 * *$ & $0.994 * *$ & $0.996 * *$ & 1.000 & \\
\hline & 0.000 & 0.000 & 0.000 & & \\
\hline \multirow[t]{2}{*}{ Muscle } & $0.993 * *$ & $0.981 * *$ & $0.979 * *$ & $0.981 * *$ & 1.000 \\
\hline & 0.000 & 0.000 & 0.000 & 0.000 & \\
\hline
\end{tabular}

Values in the top line of each tissue indicate Pearson's correlation coefficient; values in the respective bottom line indicate level of significance at $5 \%$ probability. $* *$ highly significant $(\mathrm{P}<0.01)$. 


\section{Discussion}

Water pollution affects the stability of freshwater ecosystem and can also induce genotoxicity in aquatic animals. Heavy metals, most frequently accumulate in freshwater ecosystems (Aanand et al., 2010; Omar et al., 2012). The main source of heavy metals in the area of the current study was exogenous due to either surface runoff and discharge of untreated effluents from nearby agriculture and industry (Authman and Abbas, 2007; Omar et al., 2012). The observed pollutants can cause genetic changes leading to detrimental mutations (Hussain et al., 2016). "DNA fragmentation" values recorded in the muscle of fish were within permissible limits to "that in the gills, kidney and skin". The results of our study showed a relationship of heavy metal levels in various tissues of fish and DNA fragmentation. The gills are a metabolically active organ in fish and can accumulate more heavy metals than other organs. Heavy metals catalyze reactions that generate reactive oxygen species, which may cause oxidative stress and damage to tissues and macromolecules such as DNA, proteins, and lipids. Our findings are in line with the results of other studies (Mahboob et al., 2011; Chaudhry and Jabeen, 2011; Hussain et al., 2016). These studies reported that this may be due to a repair mechanism induced in response to a reactive oxygen species that are produced by heavy metal or organic pollution. Jabeen and Chaudhry (2010) examined the muscle of $L$. rohita and O. mossambicus and reported that DNA integrity in muscle tissue was not affected by pollution, whereas DNA extracted from different organs showed severe damage, which corroborate with our findings. Gonzalez-Mille et al. (2010) reported the impact of heavy metals and other toxicants on muscle tissues of fish harvested from the Coatzacoalcos River, Mexico, and found an increase in DNA damage due to high genotoxin concentrations in the water. Almeida et al. (2005) mentioned comparatively higher concentration of metals in a river due to the deposition of waste from adjacent industrial areas. The findings of this study were also supported by Binelli et al. (2010) who reported that fluctuation pollution levels in rivers. DNA fragmentation, increased with fish weight in the examined fish species. Lima et al. (2006), Saeed and Shaker (2008) and Simone et al. (2000) reported more DNA damage in fish exposed to toxins for longer period. Liyan et al. (2005) proposed the use of DNA fragmentation as an assessment tool for heavy metal pollution. Analía et al. (2016) suggested the use of a multi-biomarker approach for the study of toxicological mechanisms caused by exposure to a combination of chromium and $\mathrm{Pb}$.

\section{Conclusions}

DNA damage can be used as a biomarker of water pollution and may be used as an early warning for pollution monitoring in freshwater ecosystems.

\section{Acknowledgements}

The authors (SM and KAAG) express their sincere appreciation to the Deanship of Scientific Research at the King Saud University for its funding of this research through the Research Group Project No. RG-1435-012.

\section{References}

AANAND, S., PURUSHOTHAMAN, C.S., PAL, A.K. and RAJENDRAN, K.V., 2010. Toxicological studies on the effect of copper, lead and zinc on selected enzymes in the adductor muscle and intestinal diverticula of the green mussel Perna viridis. Industrial Journal Marine Science, vol. 39, no. 2, pp. 299-302.

AleyA, L., KHATtABI, H., BELLE, E., GRISEY, H., MUDRY, J. and MANIA, J., 2007. Coupling of abiotic and biotic parameters to evaluate performance of combining natural lagooning and use of two sand filters in the treatment of landfill leachates. Environmental Technology, vol. 28, no. 2, pp. 225-234. http://dx.doi.org/10.1080/09593332808618785. PMid:17396417.

ALMEIDA, L., FALCAO, A., MAIA, A., MAZUR, D., GELLERT, D. and SOARES-DA-SILVA, P., 2005. Single-dose and steady-state pharmacokinetics of eslicarbazepine acetate (BIA2-093) in healthy elderly and young subjects. Journal of Clinical Pharmacology, vol. 45, no. 9, pp. 1062-1066. http:// dx.doi.org/10.1177/0091270005279364. PMid:16100301.

ANALIA, A., CARLA, B. and JIMENA, C., 2016. Responses of multiple biomarkers in the fish Hoplosternum littorale to chromium and lead. Fresenius Environmental Bulletin, vol. 25, pp. 4052-4059.

ASSOCIATION OF OFFICIAL ANALYTICAL CHEMISTRY -AOAC, 1995. Official methods of analysis. 18th ed. Arlington: AOAC.

AUTHMAN, M.M.N. and ABBAS, H.H.H., 2007. Accumulation and distribution of copper and zinc in both water and some vital tissues of two fish species (Tilapia zillii and Mugil cephalus) of Lake Qarun, Fayoum Province, Egypt. Pakistan Journal of Biological Sciences, vol. 10, no. 13, pp. 2106-2122. http://dx.doi. org/10.3923/pjbs.2007.2106.2122. PMid:19070169.

BINELli, A., COGNI, D., PAROLINI, M. and PROVINI, A., 2010. Multi-biomarker approach to investigate the state of contamination of the R. Lambro/R. Po confluence (Italy) by zebra mussel (Deissena polymorpha). Chemosphere, vol. 79, no. 5, pp. 518-528. http://dx.doi.org/10.1016/j.chemosphere.2010.02.033. PMid:20202670.

BOYD, C.E. and TUCKER, C.S., 1998. Pond aquaculture water quality management. London: Kluwer Academic Publishers. http://dx.doi.org/10.1007/978-1-4615-5407-3.

CHAUDHRY, A.S. and JABEEN, F., 2011. Assessing metal, protein, and DNA profiles in Labeo rohita from the Indus River in Mianwali, Pakistan. Environmental Monitoring and Assessment, vol. 174, no. 1-4, pp. 665-679. http://dx.doi.org/10.1007/s10661010-1486-4. PMid:20461548.

GONZÁLEZ-MILLE, D.J., ILIZALITURRI-HERNÁNDEZ, C.A., ESPINOSA-REYES, G., COSTILLA-SALAZAR, R., DÍAZ-BARRIGA, F., IZE-LEMA, I. and MEJÍA-SAAVEDRA, J., 2010. Exposure to persistent organic pollutants (POPs) and DNA damage as an indicator of environmental stress in fish of different feeding habits of Coatzacoalcos, Veracruz, Mexico. 
Ecotoxicology, vol. 19, no. 7, pp. 1238-1248. http://dx.doi. org/10.1007/s10646-010-0508-x. PMid:20563841.

HUED, A.C. and BISTONI, M.A., 2005. Development and validation of abiotic index for Evaluation of environmental quality in the central region of Argentina. Hydrobiologia, vol. 543, no. 1, pp. 279-298. http://dx.doi.org/10.1007/s10750-004-7893-1.

HUSSAIN, B., SULTANA, T., SULTANA, S., ALGHANIM, K.A. and MAHBOOB, S., 2016. Study on effect of pollution on genotoxic damage in Cirrhinus mrigala and Catla catla from River Chenab. Fresenius Environmental Bulletin, vol. 25, no. 7, pp. 2500-2508.

JABEEN, F. and CHAUDHRY, A.S., 2010. Monitoring trace metals in different tissues of Cyprinus carpio from the Indus River in Pakistan. Environmental Monitoring and Assessment, vol. 170, no. 1-4, pp. 645-656. http://dx.doi.org/10.1007/s10661009-1263-4. PMid:20033282.

LIMA, P.L., BENASSI, J.C., PEDROSA, R.C., DAL MAGRO, J., OLIVEIRA, T.B. and WILHELM FILHO, D., 2006. Timecourse variations of DNA damage and biomarkers of oxidative stress in Tilapia (Oreochromis niloticus) exposed to effluents from a Swine Industry. Archives of Environmental Contamination and Toxicology, vol. 50, no. 1, pp. 23-30. http://dx.doi.org/10.1007/ s00244-004-0178-x. PMid:16247568.

LIYAN, Z., YING, H. and GUANGXING, L., 2005. Using DNA damage to monitor water environment. Chinese Journal of Oceanology and Limnology, vol. 23, no. 3, pp. 340-348. http:// dx.doi.org/10.1007/BF02847158.

MAHBOOB, S., GHAZALA, SULTANA, S., AL-AKEL, A.S., AL-BALAWI, Al-Kahem, AL-MISEND, F. and ZUBAIR, A., 2011. Pesticide residues in flash of Cirrihina mrigala collected from a commercial farm and river Chanab at Trimu Head, Jhang. Pakistan Journal of Zoology, vol. 43, no. 1, pp. 97-100.

MAYON, N., BERTRAND, A., LEROY, D., MALBROUCK, C., MANDIKI, S.N., SILVESTRE, F., GOFFART, A., THOMÉ, J.P. and KESTEMONT, P., 2006. Multiscale approach of fish responses to different types of environmental contaminations: a case study. The Science of the Total Environment, vol. 367, no. 2-3, pp. 715-731. http://dx.doi.org/10.1016/j.scitotenv.2006.03.005. PMid:16740295.

OMAR, W.A., ZAGHLOUL, K.H., ABDEL-KHALEK, A.A. and ABO-HEGAB, S., 2012. Genotoxic effects of metal pollution in two fish species, Oreochromis niloticus and Mugil cephalus, from highly degraded aquatic habitats. Mutation Research, vol. 746, no. 1, pp. 7-14. http://dx.doi.org/10.1016/j.mrgentox.2012.01.013. PMid:22464984

PERANDONES, C.E., ILLERA, V.A., PECKHAM, D., STUNZ, L.L. and ASHMAN, R.F., 1993. Regulation of apoptosis in vitro in mature murine spleen T-cell. Journal of Immunology, vol. 151, no. 7, pp. 3521-3529. PMid:8376790.
SAEED, S.M. and SHAKER, I.M., 2008. Assessment of pollution in water and sediments and their effect on Orechromis niloticus in the Northern Delta Lakes, Egypt. In: Proceedings of the 8th International Symposium on Tilapia in Aquaculture, 2008, Cairo, Egypt. Arizona: American Tilapia Association.

SAEEDI SARAVI, S.S. and SHOKRZADEH, M., 2013. Heavy metals contamination in water and three species of most consumed fish sampled from Caspian Sea. Environmental Monitoring and Assessment, vol. 185, no. 12, pp. 10333-10337. http://dx.doi. org/10.1007/s10661-013-3335-8. PMid:23842607.

SALMAN, J.M., AL-MAMOORI, A.M.J., AL-SAADI, A.H. and AL-TERCHI, M.N., 2012. DNA damage in common carp fish (Cyprinus carpio L.) induced by acute exposure to copper and cadmium. World Applied Sciences Journal, vol. 20, no. 5, pp. 679-682.

SANTOS, I., DINIZ, M.S., CARVALHO, M.L. and SANTOS, J.P., 2014. Assessment of essential elements and heavy metals content on Mytilus galloprovincialis from river Tagus estuary. Biological Trace Element Research, vol. 159, no. 1-3, pp. 233-240. http://dx.doi.org/10.1007/s12011-014-9974-y. PMid:24763710.

SIMONE, C., TOMATI, U., GALLI, E., OWCZAREJ, M., DE MARCO, A., D'AMBROSIO, C., ALIANIELlO, F. and CORTELLINA, L., 2000. Evaluation of toxic and genotoxic activity of some composts from different origin. Fresenius Environmental Bulletin, vol. 9, no. 9-10, pp. 683-690.

SOUZA, T.D. and FONTANETTI, C.S., 2006. Micronucleus test and observation of nuclear alterations in erythrocytes of Nile tilapia exposed to waters affected by refinery effluent. Mutation Research, vol. 605, no. 1-2, pp. 87-93. http://dx.doi.org/10.1016/j. mrgentox.2006.02.010. PMid:16678473.

WANG, S. and SHI, X., 2001. Molecular mechanisms of metal toxicity and carcinogenesis. Molecular and Cellular Biochemistry, vol. 222, no. 1-2, pp. 3-9. http://dx.doi.org/10.1023/A:1017918013293. PMid:11678608.

WOOD, C.M., 2001. Toxic responses of the gill. In: D. SCHLENK and W.H. BENSON, eds. Target organ toxicity in marine and freshwater teleost. London: Taylor \& Francis, pp. 1-89.

ZHAO, Q., WANG, Y., CAO, Y., CHEN, A., REN, M., GE, Y., YU, Z., WAN, S., HU, A., BO, Q., RUAN, L., CHEN, H., QIN, S., CHEN, W., HU, C., TAO, F., XU, D., XU, J., WEN, L. and LI, L., 2014. Potential health risks of heavy metals in cultivated topsoil and grain, including correlations with human primary liver, lung and gastric cancer, in Anhui province, Eastern China. The Science of the Total Environment, vol. 470-471, pp. 340-347. http://dx.doi.org/10.1016/j.scitotenv.2013.09.086. PMid:24144938. 